\title{
THE BEHAVIOUR OF LITTORINA LITTOREA (L.) UNDER NATURAL CONDITIONS AND ITS RELATION TO POSITION ON THE SHORE
}

\author{
By G. E. Newell \\ Queen Mary College, University of London
}

(Text-figs. I and 2)

The four common species of British littorinids are all browsers (mainly on algae), and each characteristically occupies a wide but fairly well-defined zone relative to the tide marks. Littorina littorea is a normal and often common member of the gastropod population of the middle shore wherever rock or pebbles are found, and also occurs in numbers on wooden structures such as piers and groynes. More rarely is it found on sandy or muddy shores, particularly if they are sheltered and poorly drained. Only occasionally does it become established above H.W.N., whilst it decreases in numbers below E.L.w.S., even where there is good holding ground. This much is well known, but reasons have been given (Smith \& Newell, 1955) for believing that on the shore at Whitstable individual winkles tend to remain faithful to the particular beach level which they adopted during the first year of life after larval settlement.

In contrast to truly sedentary animals, such as barnacles and most lamellibranchs, winkles move about, and were their movements completely at random this constant pattern of zonation would in time be upset. (This must apply not only to littorinids, but to all intertidal animals with broadly similar habits.) An inspection of any shore at low water gives the impression after the tide has receded that the vast majority of animals are settled in situations which best protect them from desiccation, extremes of temperature, insolation and other adversities, but predators and browsers must leave such positions in order to obtain food. Yet, with a few notable exceptions the feeding excursions have not been studied in detail. The present investigation was designed to show how winkles maintain their pattern of zonation, and was done partly on the shore at Whitstable and partly in the laboratory at Queen Mary College. 


\section{THE DISTRIBUTION OF WINKLES ON THE SHORE AT WHITSTABLE}

The distribution of the winkle population shows no general relation to gravity, light, tidal level or beach slope. Nor does desiccation, itself correlated with time of exposure and tidal level, seem obviously to affect the density of the population. Some winkles are found on top of stones, others at the sides of stones and others again on the vertical surfaces of groynes. It is true that those winkles on vertical surfaces always come to rest with their anterior ends uppermost, but on stones an apparently random orientation prevails.
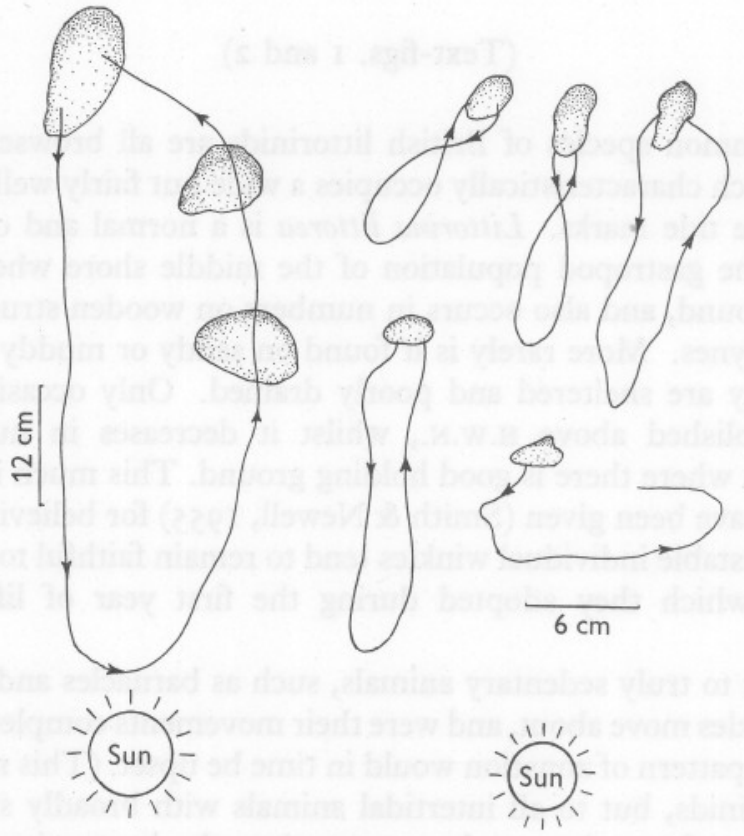

Fig. I. Selection of tracks made by winkles crawling in the sand near mid-tide level in bright sunlight. September 1956.

Although winkles seem to be distributed in an apparently random way if broadly viewed, they can be noticed to aggregate and form clusters, especially at the junction of two surfaces as, for example, where planking joins a post on a groyne, and also in pools, where winkles are obviously more densely congregated than in drier situations.

On certain parts of the beach, patches of fine sand are interspersed with pebbles and these serve to record the tracks made by winkles when crawling. Such tracks are roughly $U$-shaped and can often be seen to radiate out from and back to stones on which the animals have settled. 
On the vertical surfaces, such as the planking of groynes, winkle tracks are less obvious but, under favourable conditions, they can be seen to take the form of a downward, horizontal and upward limb. In this they resemble the U-shaped tracks in the sand.

During the summer months, when winkles are most active, the tracks in the sand give no clear indication of uniform orientation. Indeed, they appear to be completely random, but, as will be shown later, this appearance is misleading and the apparent randomness of their direction is attributable to the difficulty of following by eye alone a maze of criss-crossing tracks. Yet the very fact that all tracks pursue a fairly straight course for some considerable distance is, in itself, suggestive of orientated responses. The vast majority (roughly $95 \%$ ) of these tracks consist of an outward and a homeward limb and some that appear to consist of a single limb only may be of the same general form, one limb having been obliterated by wavelets if crawling had begun before the tide had left the zone completely. Examples of some of these tracks are shown in Fig. I. A few winkles pursue a fairly steady course and show no reversal of direction, but the reason for this is not known.

When crawling on stones winkles can be observed to feed by rasping off organic surface deposits such as diatoms and small algae. They will also browse on Ulva and Enteromorpha. Indeed, certain areas of groynes are kept clear of Enteromorpha by this means, and it must be supposed that any winkle quickly exhausts the food supply in the immediate vicinity of the place on which it has settled.

\section{THE MAINTENANCE OF ZONATIONAL POSITION}

Gowanloch \& Hayes (I926) presented evidence, from observations on marked specimens, that winkles migrate back to the particular level on which they normally dwelt, after displacement to other situations, whilst Moore (I936), who marked winkles with cellulose paint with a view to following the growth rates of particular specimens, was able to re-collect many of these quite considerable periods after their replacement in roughly the same area. Many of Gowanloch \& Hayes's specimens got lost and their results are somewhat equivocal, so that further observations are desirable, particularly since they state that winkles seem to move a few metres at each tide-a view which conflicts with observations recorded in the present paper.

The following observations are typical of several which have been made on the shore at Whitstable, and they show that, if left undisturbed, winkles will return to similar but not necessarily identical positions, and that if removed from the place where they have settled, their chances of getting back home are reduced.

Ten winkles, clustered around a hexagonal nut joining the planking to a wooden groyne post at about the level of H.W.N., were each marked with a dab 
of yellow enamel before the tide reached them at $13.15 \mathrm{~h}$ on 25 September I956. Twenty-four hours later, i.e. after two tides, five winkles were in the same position, two were within I ft. on the planking whilst three could not be found. On 27 October, I month later, five were still within 4 yd. of the nut and of these, one was still on the nut itself. On 28 December 1956, one winkle was still on the nut, three were within $5 \mathrm{yd}$. on the planking whilst the rest could not be found. In short, these observations show that winkles remain restricted to a particular situation, and it must be stressed that the situation studied was one in which the winkles were in a most unstable state and were subject to severe wave action-far more severe than if they had been on horizontal surfaces.

Twenty winkles were clustered one above the other along the junction of a vertical post with the planking of a groyne. Of these, ten were left undisturbed and were marked with a spot of blue paint, whilst ten were lifted and marked with a spot of yellow as well as blue paint and then placed in the muddy sand $2 \mathrm{ft}$. away from the base of the groyne. After $24 \mathrm{~h}$, i.e. two tides later, of the undisturbed winkles three were in exactly the same place, two were in a similar situation but on the next post, two were at the base of the groyne whilst three could not be found. Of those which had been removed by $2 \mathrm{ft}$. from their place of settlement, two were in the same place, two in a corresponding position on the next post and six could not be found. After 4 weeks only five winkles marked with a spot of blue paint could be found, but all were within $5 \mathrm{yd}$. of their original position. None with yellow and blue spots were found. This shows that displacement from the site of settlement tends to decrease the chances of a winkle getting back to its original position.

It must be realized that under natural conditions winkles are continually liable to displacement by wave-action, but that this is usually limited to the time at which waves are breaking over the zone on which they have settled, and once they have been covered by the advancing tide wave-action is too slight to dislodge them except on very steep parts of the shore. Winkles settled on very dry situations and adhering merely by the adhesive action of a film of dried mucus instead of by the foot are particularly liable to be dislodged, but there is reason to suppose that those animals sticking to stones or groynes by the adhesive action of the foot are not often detached from their place of settlement. This has been confirmed by numerous observations on the shore. It is also clear from considerations of the relation of the efficiency of wave-action relative to beach-face slope (Newell, 1954) that high-level winkles are more liable to displacement by waves than those on the flatter slopes below H.W.N. Yet the previous results (Smith \& Newell, 1955) show that the exchange of winkles between beach levels is strictly limited, whilst observations on marked winkles moved to different situations gave no evidence that the animals return to the particular level from which they were collected.

Before the tide has ebbed to its finality, practically all winkles are at rest. 
Those on groynes or on dry stones settle down almost as soon as the water leaves them, but those in pools crawl about for periods of up to about $3 \mathrm{~h}$ after the tide has receded. But eventually even those left in situations where they are permanently covered by water become quiescent, as is shown by an observation of $\mathrm{I}_{4}$ September (a time of the year when winkles are still very active), when out of forty-five winkles in a shallow pool near mid-tide level, forty-three had settled down $5 \frac{1}{2} \mathrm{~h}$ after full tide. Yet, as soon as the flood tide reaches them, all the winkles begin active crawling once again.

These observations suggest that winkles remain stationary during the greater part of each tide even when they are submerged, whereas Haseman (I9II) believed that they crawled continuously 'at random' when covered by water and that their activities ceased only when they were out of water on dry surfaces, a view which is implicit in the writings of others, for example Kanda (I9I6) and Barkman (I955). It would, of course, be most interesting to follow the movements of individual winkles for some time after the tide had covered them, but this is practically impossible in the turbid water at Whitstable. Nevertheless, results, which are probably comparable to those which would have been obtained under natural conditions, can be arrived at by a study of winkles in a tank with a fluctuating water level.

\section{ADHESION}

Winkles on vertical or steeply inclined surfaces almost invariably come to rest with their anterior ends uppermost. After some time of exposure many of them secrete a film of mucus (as noted by Wilson, 1929) around the rim of the shell and this hardens sufficiently to support the animal's weight. Then the foot is withdrawn and the operculum closed so that the animal is in no danger of rapid desiccation. Wilson noted that a mere puff of wind will topple winkles from the rocks to which they are stuck by mucus, and further states that those which come to rest with the head downwards always topple off when the foot retracts. I have been unable to confirm this last observation of Wilson's. Indeed, on the contrary, as can easily be demonstrated, winkles are far more unstable on sloping surfaces when orientated head-uppermost than when the head is downwards. This is at first sight somewhat surprising, but this very instability has survival value in that, should any winkle come to rest above the high water mark, the slightest disturbance will cause it to roll down to a level which will be reached by the next tide and so avoid the possibility of not being wetted, possibly, until a fortnight later.

\section{CRAWLING AND FEEDING}

When a winkle is about to begin to crawl, the foot and head are protruded through the shell aperture and the operculum on the metapodial region is turned upwards and backwards above the mesopodial region so that the 
creeping sole of the foot can be applied to the substratum. When crawling on either a vertical or a horizontal surface winkles continually 'test' it with their tentacles, which are extended obliquely outwards from the head, but not at any constant angle for they are in almost continual movement, first the right and then the left feeling the substratum. At first sight it would seem that these bending movements of the tentacles, on which it will be remembered the eyes are borne, would preclude the possibility of the animals maintaining any constant orientation to light, but observations made it clear that only that part of the tentacle distal to the eye is involved in the bending and so the eyes maintain a steady position during crawling (Fig. 2). The degree of extension of the head is such that the eyes, placed about one-third of the way up the tentacles, are a short way in front of the pigmented edge of the mantle, which, with the shell, prevents light from the rear from entering them.

It can also be noticed that when crawling the animal makes feeding movements, the radula being alternatively protruded and retracted about once every second.

The rate of crawling on wet sand, as determined by an average of twelve specimens on I4 September 1956, was $2 \mathrm{~cm} / \mathrm{min}$, which is in very good agreement with the figures of Gowanloch \& Hayes (1926) who give an average rate of

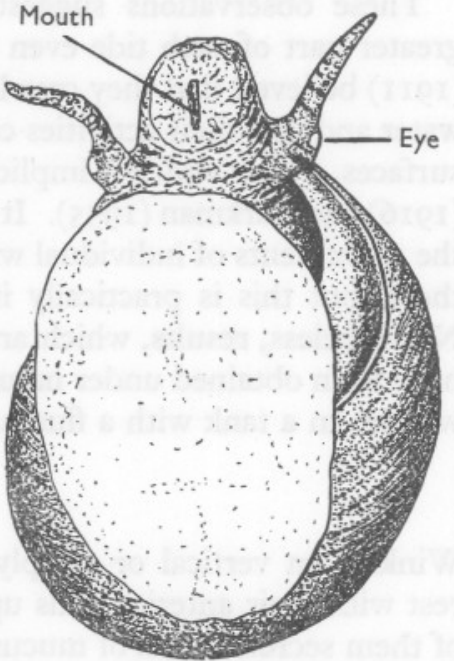

Fig. 2. Winkle crawling on a glass plate-viewed from below. crawl on rock surfaces as $\mathrm{I} \cdot 3 \mathrm{~m} / \mathrm{h}$ which equals $2 \cdot \mathrm{I} \mathrm{cm} / \mathrm{min}$. It was found, however, that in the laboratory, either on vertical or horizontal glass plates, winkles can attain a rate of crawl of $10 \mathrm{~cm} / \mathrm{min}$. The rate of crawling seems, in part, to depend on the temperature (see p. 236).

In bright light active winkles always respond to a sudden decrease in light intensity by a rapid but momentary withdrawal into the shell. That is, they respond in the same manner as to any other sudden change in the environment, but the withdrawal response to shadows quickly wanes.

\section{FACTORS INFLUENCING THE SEASONAL ACTIVITIES OF WINKLES}

So far the account of the behaviour of winkles on the shore at Whitstable has been confined to that seen in the autumn, which is substantially true for the spring and summer months also. But from November onwards, through the winter until March, the winkle population is largely inactive. For example, 
on 17 November 1956, a dull, calm day, practically no winkle tracks were discernible. On the following day, with the sun showing as a clear disc through the mist, only one winkle was seen to be moving after the tide had receded. The same inactivity on the shore prevailed throughout December and January, but during the exceptionally warm February of 1957 winkle tracks were again apparent, although in nothing like the profusion noticed in the early autumn of 1956 .

Observations of this kind suggest that winkles become inactive when the light intensity and temperature are low, and it is possible that these environmental factors of the winter act either singly or in combination. It is of interest in this connexion that Moore (1936) found that the growth rates of winkle populations in the Plymouth neighbourhood slowed down from October to February.

A few laboratory results will be quoted to show that both low light intensity and decreased temperatures lower the level of activity.

\section{VARIATION IN RATE OF CRAWLING UNDER DIFFERENT LIGHT INTENSITIES}

Individual winkles collected from horizontal surfaces and dark-adapted for $6 \mathrm{~h}$ were tested for rate of crawling under varying conditions of light intensity. These were obtained with an overhead light and a rheostat. The results are set out below. It will be seen that winkles behave orthokinetically in response to strong variations in light intensity, and it is likely that this has some importance in stimulating the animals to crawl and feed (Table I).

TABLE 1. DISTANCE (CM) CRAWLED IN 5 MIN AT $19^{\circ} \mathrm{C}$

\begin{tabular}{ccc} 
Winkle & \multicolumn{2}{c}{ At light intensity of } \\
number & Io f.c. & $3000 \mathrm{f} \mathrm{c.}$ \\
I & 22.0 & 27.0 \\
2 & 22.5 & 30.0 \\
3 & 17.2 & 24.3 \\
4 & 16.0 & 17.0
\end{tabular}

\section{VARIATIONS IN RATE OF CRAWL AT DIFFERENT TEMPERATURES}

Individual winkles collected from horizontal surfaces and dark-adapted for $6 \mathrm{~h}$ were tested for rate of crawling at different temperatures (Table 2).

In each instance increase in temperature induced an increased rate of crawl. Further experiments were, therefore, carried out to determine the temperature at which winkles become immobilized.

Twelve winkles from vertical surfaces were placed in a dish of sea water at $0^{\circ} \mathrm{C}$ and illuminated from above at an intensity at the water surface of $\mathrm{ro}$ f.c. All remained completely inactive for $20 \mathrm{~min}$. Then the water was allowed to warm up gradually (see Table 3 ). 
Twelve winkles from vertical surfaces were placed in a dish of sea water at I I ${ }^{\circ} \mathrm{C}$ illuminated from above at an intensity of ro f.c. All began to crawl actively straightaway at a rate of about $2.5 \mathrm{~cm} / \mathrm{min}$. The water was then cooled gradually (see Table 4).

TABLE 2. DISTANCE (CM) CRAWLED IN 5 MIN

\begin{tabular}{ccc} 
Winkle & \multicolumn{2}{c}{ Temperature } \\
\cline { 2 - 3 } $\begin{array}{c}\text { I } \\
\text { number }\end{array}$ & $\begin{array}{r}12^{\circ} \mathrm{C} \\
10.5\end{array}$ & $25^{\circ} \mathrm{C}$ \\
2 & 10.4 & 17.8 \\
& $8^{\circ} \mathrm{C}$ & 15.7 \\
3 & 12.0 & $19^{\circ} \mathrm{C}$ \\
4 & 20.5 & 19.5 \\
5 & 7.3 & 30.0 \\
6 & 9.5 & 22.8 \\
& 25.5
\end{tabular}

TABLE 3. EFFECT OF TEMPERATURE ON ACTIVITY

At $3^{\circ} \mathrm{C}$ I became active, i.e. put out its tentacles but did not crawl

$4^{\circ} \mathrm{C} 2$ became active, i.e. put out their tentacles but did not crawl

$5^{\circ} \mathrm{C} 7$ became active, i.e. put out their tentacles but did not crawl

$6^{\circ} \mathrm{C} 8$ became active, and 3 of these began to crawl slowly

$8^{\circ} \mathrm{C}$ I2 became active, and 8 of these were crawling slowly

$10^{\circ} \mathrm{C}$ I2 were crawling at a rate of $2.5 \mathrm{~cm} / \mathrm{min}$

TABLE 4. EFFECT OF TEMPERATURE ON RATES OF CRAWLING

At $\begin{aligned} 10^{\circ} \mathrm{C} \text { Io were crawling at a rate of about } 1.5-2.0 \mathrm{~cm} / \mathrm{min} \\ 8^{\circ} \mathrm{C} \quad 8 \text { were crawling at a rate of about } 1.0-1.5 \mathrm{~cm} / \mathrm{min} \\ 7^{\circ} \mathrm{C} \quad 7 \text { were crawling at a rate of about } 0.5-1.0 \mathrm{~cm} / \mathrm{min}\end{aligned}$

(the rest were inactive)

These results show that at temperatures of between $6^{\circ}$ and $8^{\circ} \mathrm{C}$ winkles become inactive even when illuminated at light intensities sufficient to promote crawling at higher temperatures. They serve to explain why they remain largely inactive in the winter months from November to March when air and sea temperatures at Whitstable are usually below $8^{\circ} \mathrm{C}$, although bright sunlight may occur at the time of low water. Indeed, observation on the shore makes it clear that low temperatures, rather than low light intensity, inhibit feeding migrations.

An interesting corollary of the relation between activity and temperature is that winkles which have settled on horizontal surfaces and which make their feeding excursions in the shallow layer of water covering them as the tide recedes may, in the warmer months of the year, experience temperatures well above those of the sea itself and so their feeding excursions are correspondingly longer, as can be noticed by a comparison of the tracks in the sand and on groynes.

\section{DISCUSSION}

In short, these observations made on the shore give the impression that winkles remain settled for a considerable part (probably the greater part) of each tidal period but that on occasions they undertake feeding excursions. 
These excursions, as shown by tracks in the sand or on groynes, are reminiscent of the 'outward and homeward' journeys performed by many invertebrate animals, notably arthropods, but which are also known to be made very precisely by limpets (e.g. various species of Patella), less precisely by other shore gastropods, such as Onchidium and by chitons, as well as by some landdwelling gastropods. Few of the homing reactions of intertidal gastropods have received detailed analysis and Thorpe (1956), commenting on the homing of limpets, remarks that: 'Apparent place memory has been observed in a number of other marine and intertidal gastropods, but the basis of it has not been properly investigated.'

The 'homing' reactions of winkles are, perhaps, comparable with those described and analysed by Evans (195I) for the small chiton, Lepidochitona cinerea, and evidently they tend to confine any particular winkle for a period of weeks or even months to an area of a few square metres, from which, however, it may become displaced by wave-action. Evans showed that at low tide $L$. cinerea is invariably found on the undersides of damp stones; that the animals move away from a strong directional light source but that they also have a strong positive orthokinetic response (so tending to accumulate in dark situations); that they are positively geotactic when out of water but are indifferent to the stimulus of gravity when immersed, and that a combination of these reactions to common stimuli serves to explain their ability to shelter under stones at low tide, whilst at high water allowing them to carry out feeding migrations. The rather limited excursions of these small chitons receive, then, explanation without recourse to 'place memory'. But, bearing in mind the more varied situations in which winkles are to be found at the time of low water, it is apparent that their reactions are likely to be less stereotyped than those of Lepidochitona although their feeding migrations may still be orientated by responses to light and to gravity. Thus, the vertical $\mathrm{U}$-shaped tracks made by those which settle either on the east or west faces of groynes in regions of light or shade, exposed or in cracks, cannot, it would seem, be the result of movements orientated solely with respect to the direction or intensity of light. Rather they suggest excursions determined by gravity responses. On the other hand, it is inconceivable that the tracks made on the virtually horizontal surface of sandy patches owe anything to gravity responses. Indeed, the only directional stimulus would seem to be that of light from the sun to which at least one marine mollusc, viz. the opisthobranch Elysia viridis is known to orientate by performing a light-compass reaction (Fraenkel, 1927). A more detailed review of the literature on the behaviour of winkles is given in the article that follows in this Journal (p. 24I). 


\section{SUMMARY}

On the flat shore at Whitstable the population of common winkles is distributed appreciably at random over a variety of substrata ranging from wooden groynes, through shingle to muddy sand, between tidal levels corresponding to H.W.N.-E.L.W.S. but with a maximum density near M.T.L., although aggregations tend to occur in wetter situations and where planking joins vertical groyne posts.

Observations on winkles marked with a dab of paint of distinctive colour show that they tend to remain in approximately the same position for many weeks.

For most of each tidal period winkles remain settled in situations such as stones or groynes, which provide good holding ground, but as the tide recedes or the incoming tide reaches them, they become activated to crawl, feeding meanwhile. These feeding migrations are recorded in the sand by roughly $\mathrm{U}$-shaped tracks and can be seen under favourable circumstances as similar tracks in the vertical plane for winkles on groynes. By such excursions the animals are enabled to move, feed and return to approximately the place from which they started and this serves to explain how they maintain their station on the shore.

When settled on vertical surfaces, winkles always orientate with the head uppermost, when the foot may be withdrawn and the animal become attached by a film of dried mucus.

When crawling the eyes are exposed and the tentacles bend to test the substratum, but only that part of the tentacle distal to the eye bends so that the optical axis of the eye maintains a constant angle to the body axis.

Winkles are inactive during the winter and laboratory tests show that crawling ceases at about $8^{\circ} \mathrm{C}$. The animals also behave orthokinetically in response to strong variations in light intensity, crawling faster at higher light intensities.

\section{REFERENCES}

BARKMAN, J. J., I955. On the distribution and ecology of Littorina obtusata (L.) and its specific units. Arch. néerl. Zool., T. I I, pp. 22-86. den Helder.

Evans, F. G. C., 195I. An analysis of the behaviour of Lepidochitona cinereus in response to certain physical features of the environment. F. Anim. Ecol., Vol. 20, pp. I-IO.

Fraenkel, G., 1927. Die Photomenotaxis von Elysia viridis. Z. vergl. Physiol., Bd. 6, pp. $167-220$.

GoWANLOCH, J. N. \& HaYes, F. R., 1926. Contributions to the study of marine gastropods. I. The physical factors, behaviour and intertidal life of Littorina. Contr. canad. Biol., N.S., Vol. 3, pp. 135-65.

Haseman, J. D., I9II. The rhythmical movements of Littorina littorea synchronous with ocean tides. Biol. Bull., Woods Hole, Vol. 21, pp. II3-I2I.

KANDA, S., 1916. Studies of the geotropism of the marine snail, Littorina littorea. Biol. Bull., Woods Hole, Vol. 30, pp. 57-84. 
Moore, H. B., 1936. The biology of Littorina littorea. Part I. Growth of the shell and tissues, length of life and mortality. F. mar. biol. Ass. U.K., vol. 21, pp. $72 \mathrm{I}-42$.

Newell, G. E., 1954. Animal zones on the North Kent Coast. S. East. Nat., Vol. 59, pp. $34-56$.

SMITH, J. E. \& Newell, G. E., I955. The dynamics of the zonation of the common periwinkle (Littorina littorea (L.)) on a stony beach. F. Anim. Ecol., Vol. 24, pp. $35-56$.

THORPE, W. H., 1956. Learning and instinct in animals. London: Methuen.

WILson, D. P., I929. A habit of the common periwinkle (Littorina littorea Linn.). Nature, Lond., Vol. I24, p. 443. 